\title{
Activation of Potassium Channels Contributes to Hypoxic Injury in Proximal Tubules
}

\author{
W. Brian Reeves and Sudhir V. Shah \\ Division of Nephrology, University of Arkansas for Medical Sciences, Little Rock, Arkansas 72205
}

\begin{abstract}
The mechanisms responsible for the loss of cell potassium during renal ischemia are poorly understood. The present studies examined the hypothesis that potassium channels are activated as an early response to hypoxia and contribute to potassium loss independent from an inhibition of active $\mathrm{K}^{+}$uptake. Potassium flux in suspensions of freshly isolated rat proximal tubules was measured using an ion-selective electrode. Exposure of the tubules to hypoxia for only 2.5 min resulted in a rise in the passive leak rate of $\mathrm{K}^{+}$but no decrease in active $\mathrm{K}^{+}$uptake. The passive leak of $\mathrm{K}^{+}$was associated with a $40 \%$ decrease in cell ATP content. The passive $\mathrm{K}^{+}$efflux was inhibited by $5 \mathrm{mM} \mathrm{Ba}^{2+}(95 \%)$ and by $15 \mathrm{mM}$ tetraethylammonium $(85 \%)$ suggesting that $K^{+}$ channels were the primary route of $\mathrm{K}^{+}$movement. The effects of $\mathrm{K}^{+}$channel blockade on the development of hypoxic injury were also examined. Tetraethylammonium and glibenclamide, an inhibitor of ATP-sensitive $\mathrm{K}^{+}$channels, reduced hypoxic injury as assessed by the release of lactate dehydrogenase or measurement of DNA damage. These results suggest that activation of $\mathrm{K}^{+}$channels is an early response to hypoxia and contributes to hypoxic renal injury. (J. Clin. Invest. 1994. 94:2289-2294.) Key words: kidney • $\mathrm{K}^{+}$channels $\cdot$ hypoxia $\cdot$ glibenclamide $\cdot$ DNA damage
\end{abstract}

\section{Introduction}

Two of the earliest events documented after the onset of renal ischemia are a loss of intracellular potassium and a reduction in cellular ATP levels. In the study of Takano et al. (1), for example, rabbit proximal tubules lost $\sim 60 \%$ of their cellular potassium within the first $10 \mathrm{~min}$ of in vitro hypoxia. Similarly, measurements of cellular ATP levels during either in vivo or in vitro renal ischemia have documented a rapid fall in ATP during the first few minutes of ischemia (2-4). The loss of cellular $\mathrm{K}^{+}$observed by Takano et al. (1) and others $(4,5)$ reflects an imbalance between the rate of active $\mathrm{K}^{+}$uptake via the $\mathrm{Na}, \mathrm{K}-\mathrm{ATPase}$ pump and the rate of passive $\mathrm{K}^{+}$efflux. While the cellular $\mathrm{K}^{+}$loss has been attributed to a decrease in $\mathrm{Na}, \mathrm{K}$ ATPase activity (6), the relative contributions of alterations in the $\mathrm{K}^{+}$pump and leak rates to the loss of cell $\mathrm{K}^{+}$during renal

Address correspondence to W. Brian Reeves, M.D., Division of Nephrology, Slot \#501, University of Arkansas for Medical Sciences, 4301 W. Markham St., Little Rock, AR 72205.

Received for publication 24 June 1994 and in revised form 25 August 1994.

J. Clin. Invest.

(C) The American Society for Clinical Investigation, Inc.

0021-9738/94/12/2289/06\$\$2.00

Volume 94, December 1994, 2289-2294 ischemia have not been examined. In particular, the role of potassium channels in the loss of cellular $\mathrm{K}^{+}$during ischemia has never been studied.

ATP-sensitive $\mathrm{K}^{+}$channels are present in the basolateral membrane of the proximal tubule $(7,8)$ where they account for the majority of the cation conductance of that membrane and are responsible for recycling $\mathrm{K}^{+}$which enters the cell via the Na,K-ATPase. The activity of these channels is regulated by cellular ATP concentrations such that a fall in ATP increases the activity of the channels. Accordingly, it seems reasonable to propose that ATP-sensitive $\mathrm{K}^{+}$channels in the proximal tubule may be activated during renal ischemia and may play an important role in the loss of cellular $\mathrm{K}^{+}$in that setting.

The pathophysiologic consequences of potassium channel activation during renal ischemia have never been examined. Recent work by Ueda and Shah has shown that DNA damage is an early consequence of renal ischemia. ${ }^{1}$ Potassium channel blockers have been shown to prevent the DNA damage caused by temperature shifts in P815 tumor cells (9). The role of potassium channels, and ATP-sensitive $\mathrm{K}^{+}$channels in particular, in the pathogenesis of DNA damage in the kidney has never been addressed.

The present studies examined the effects of hypoxia on the rate of $\mathrm{K}^{+}$efflux from isolated rat renal proximal tubules. The results indicate that the $\mathrm{K}^{+}$loss which occurs during early hypoxia results from increased rates of passive $\mathrm{K}^{+}$leak rather than decreased rates of active $\mathrm{K}^{+}$uptake. Moreover, the increased rates of $\mathrm{K}^{+}$efflux occurred coincident with a $40 \%$ fall in cellular ATP levels. The role of ATP-sensitive $\mathrm{K}^{+}$channels in the pathogenesis of ischemic injury was also examined. Blockade of $\mathrm{K}^{+}$ efflux with either tetraethylammonium (TEA) ${ }^{2}$ or glibenclamide, an inhibitor of ATP-sensitive $\mathrm{K}^{+}$channels, reduced hypoxia-induced lactate dehydrogenase $(\mathrm{LDH})$ release and DNA damage.

\section{Methods}

Preparation of tubule suspensions. Rat proximal tubules were isolated by collagenase digestion and Percoll gradient centrifugation as described by Doctor and Mandel (10). The isolated proximal tubules were resuspended at a concentration of $\sim 0.5-1 \mathrm{mg}$ protein $/ \mathrm{ml}$ and equilibrated for $30 \mathrm{~min}$ at $37^{\circ} \mathrm{C}$ in a solution containing $(\mathrm{mM}): 103 \mathrm{NaCl}, 5 \mathrm{KCl}$, $2 \mathrm{NaH}_{2} \mathrm{PO}_{4}, 1 \mathrm{MgSO}_{4}, 1 \mathrm{CaCl}_{2}, 5$ glucose, 5 malate, 5 glutamate, 4 lactate, 1 alanine, 1 valerate, 0.2 dextran-40, $20 \mathrm{Hepes,} \mathrm{and} 20 \mathrm{NaHCO}_{3}$ under a $95 \% \mathrm{O}_{2} / 5 \% \mathrm{CO}_{2}$ atmosphere before experiments.

Effect of hypoxia on $L D H$ release and DNA damage. After the 30min equilibration period, the tubules were pelleted by centrifugation and resuspended in the same solution at a protein concentration of $0.5-$

1. Ueda, N., and S. V. Shah, manuscript submitted for publication. 2. Abbreviations used in this paper: CFTR, cystic fibrosis transmembrane conductance regulator; LDH, lactate dehydrogenase; TEA, tetraethlyammonium. 
$1.0 \mathrm{mg} / \mathrm{ml}$. Aliquots of tubules $(6-10 \mathrm{ml})$ were dispensed into small Erlenmeyer flasks and incubated in a rotary shaking water bath at $37^{\circ} \mathrm{C}$. Throughout the incubation, the flasks were gassed continuously with either $95 \% \mathrm{O}_{2} / 5 \% \mathrm{CO}_{2}$ (normoxia) or $95 \% \mathrm{~N}_{2} / 5 \% \mathrm{CO}_{2}$ (hypoxia). At the end of $30 \mathrm{~min}$ of incubation under either normoxic or hypoxic conditions, aliquots of tubules were removed for measurement of LDH release $(1.5 \mathrm{ml})$ or double-stranded DNA content $(4.5 \mathrm{ml})$. Unless indicated otherwise, test agents were added at the beginning of the incubation.

The LDH activities in the supernatant and in a tubule lysate were determined spectrophotometrically from the oxidation of NADH (11). LDH release into the supernatant was expressed as a percentage of the total LDH.

DNA damage was determined using the alkaline unwinding assay $(12,13)$. In this assay, the rate of DNA unwinding under mild alkaline conditions is increased by the presence of either single or double strand DNA breaks. The amount of residual double-stranded DNA remaining at the end of the alkaline treatment is determined from the fluorescence of ethidium bromide (tube P). The fluorescence from non-DNA components in the sample was determined from a second tube (tube B) which was sonicated before the alkaline incubation to introduce a large number of strand breaks so that there was complete unwinding of the DNA. The total fluorescence (tube T) was determined from DNA not exposed to alkaline conditions $(\mathrm{pH}<11)$ so that unwinding was minimized. The amount of residual double-stranded DNA in tube $P$ was expressed as a fraction of the total DNA in the sample using the equation: percentage of residual DS-DNA $=(\mathrm{P}-\mathrm{B}) /(\mathrm{T}-\mathrm{B}) \times 100(12)$.

Effects of short-term hypoxia on net $K^{+}$flux and ATP content. Tubules were prepared as above and resuspended in a solution containing (mM): $130 \mathrm{NaCl}, 4 \mathrm{KCl}, 1 \mathrm{CaCl}_{2}, 1 \mathrm{MgCl}_{2}, 10 \mathrm{Hepes}, 5$ glucose ( $\mathrm{pH}$ 7.4). 1-ml aliquots of tubules were transferred to a water-jacketed, magnetically stirred chamber with ports for an ion-selective electrode and a reference electrode and were bubbled with $100 \% \mathrm{O}_{2}$ for 2.5 $\mathrm{min}$. After the 2.5-min equilibration, the tubules were incubated for an additional $2.5 \mathrm{~min}$ while being bubbled with either $100 \% \mathrm{O}_{2}$ (normoxia) or $100 \% \mathrm{~N}_{2}$ (hypoxia). In technical control experiments it was determined that the percentage of $\mathrm{O}_{2}$ saturation at the end of the normoxic and hypoxic incubation was $96.8 \pm 1(n=5)$ and $0.9 \pm 0.1 \%(n=3)$, respectively.

Net $\mathrm{K}^{+}$fluxes were measured with a solid-state extracellular $\mathrm{K}^{+}$selective electrode (Kwikpot; World Precision Instruments, Inc., Sarasota, FL) as described (14-16). The electrode output, referenced against an $\mathrm{Ag}-\mathrm{AgCl}$ electrode connected to the chamber by a $1 \mathrm{M} \mathrm{NaCl}$ bridge, was filtered at $2 \mathrm{~Hz}$ through an 8-pole low pass Bessel filter (902LPF; Frequency Devices, Inc., Haverhill, MA) and recorded on a chart recorder. The slope of the $\mathrm{K}^{+}$-selective electrode was 56.9 \pm 1.8 $\mathrm{mV}$ per decade change in $\mathrm{K}^{+}$concentration $(n=5)$. At the end of the 2.5-min incubation, $\mathrm{K}^{+}$uptake via the $\mathrm{Na}, \mathrm{K}$-ATPase was inhibited by the addition of $5 \mathrm{mM}$ ouabain $(17,18)$. The rate of rise in extracellular $\mathrm{K}^{+}$in the $30 \mathrm{~s}$ after the addition of ouabain was determined as a measure of the total leak rate of $\mathrm{K}^{+}$from the tubules. The reported flux rates are the means of three to four determinations under each condition on tubules from a given preparation. The rates of potassium flux were normalized to tubule protein content.

The effects of short-term hypoxia on the ATP content of the tubules were determined from aliquots of tubule suspension removed at the beginning and the end of the 2.5 -min incubation. $400-\mu 1$ samples were centrifuged through a layer of phthalate into a cushion of $10 \%$ perchloric acid. The perchloric acid extract was neutralized with $\mathrm{KOH}$ and then diluted 500-1,000-fold with a $10 \mathrm{mM}$ Tris ( $\mathrm{pH} \mathrm{7.5)} \mathrm{buffer.} \mathrm{The} \mathrm{ATP}$ content of the diluted sample was determined by mixing $20 \mu \mathrm{l}$ of sample with $100 \mu \mathrm{l}$ of a $10 \mathrm{mg} / \mathrm{ml}$ solution of luciferin-luciferase (Sigma Chemical Co., St. Louis, MO) while measuring the luminescence in a luminometer (model TD-20e; Turner Designs, Sunnyvale, CA).

Materials. Diazoxide was obtained as a $65 \mathrm{mM}$ solution in $0.1 \mathrm{~N}$ sodium hydroxide (Schering-Plough Corp., Kenilworth, NJ), all other chemicals were obtained from Sigma Chemical Co. Glibenclamide was added to solutions from a $100 \mathrm{mM}$ stock solution in DMSO. Ouabain

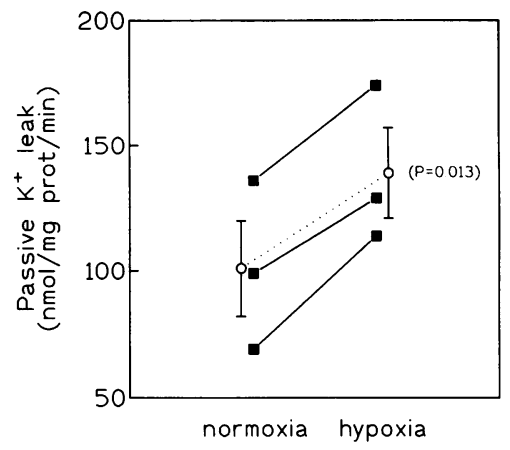

Figure 1. Effect of hypoxia on passive $\mathrm{K}^{+}$leak from proximal tubules. Proximal tubules in suspension were incubated for 2.5 min under normoxic or hypoxic conditions (see Methods). 5 $\mathrm{mM}$ ouabain was added to the suspension to inhibit active $\mathrm{K}^{+}$uptake, and the net rate of $\mathrm{K}^{+}$efflux was determined using a $\mathrm{K}^{+}$-selective electrode $(14,16)$. Each point represents the mean of three to four replicates. Lines connect data from the same tubule preparation.

was added to solutions as a $500 \mathrm{mM}$ stock solution in DMSO. TEA, when present, replaced an equimolar concentration of sodium.

\section{Results}

The effect of short-term (2.5-min) hypoxia on the passive leak rate of potassium from rat proximal tubules in suspension was determined using an extracellular $\mathrm{K}^{+}$-sensitive electrode. To isolate the passive component of $\mathrm{K}^{+}$transport, $5 \mathrm{mM}$ ouabain was added to inhibit active $\mathrm{K}^{+}$uptake via the $\mathrm{Na}, \mathrm{K}$-ATPase. This concentration of ouabain results in over $95 \%$ inhibition of $\mathrm{Na}, \mathrm{K}-\mathrm{ATPase}$ activity in the rat kidney $(17,18)$. Fig. 1 shows the effects of $2.5 \mathrm{~min}$ of hypoxia. on the rate of passive $\mathrm{K}^{+}$ efflux from proximal tubules. In each of three experiments on separate preparations of tubules, the potassium leak rate was increased during hypoxia. In these experiments basal net $\mathrm{K}^{+}$ flux rates were measured over the $30 \mathrm{~s}$ before the addition of ouabain, leak rates were measured over the $30 \mathrm{~s}$ after the addition of ouabain, and $\mathrm{Na}, \mathrm{K}$-ATPase rates were calculated as the difference between the basal and ouabain-stimulated leak rates. Hypoxia caused a slight, but not statistically significant increase in the basal rate of net $\mathrm{K}^{+}$flux $(6.7 \pm 2.2$ vs. $19.2 \pm 5 \mathrm{nmol} / \mathrm{mg}$ of protein per minute). In contrast, the passive leak rate for potassium (Fig. 1) was significantly enhanced by hypoxia. Moreover, the rate of $\mathrm{Na}, \mathrm{K}-\mathrm{ATPase}-$ mediated $\mathrm{K}^{+}$uptake by hypoxic tubules $(119.8 \pm 22.8 \mathrm{nmol} / \mathrm{mg}$ of protein per minute) was actually increased over the rate in normoxic tubules (94.3 $\pm 19.9 \mathrm{nmol} / \mathrm{mg}$ of protein per minute, $P<0.05, n=3$ ).

The pathways responsible for the potassium leak were examined by adding either barium or TEA to the tubule suspension after the addition of ouabain. $5 \mathrm{mM}$ barium reduced the rate of passive $\mathrm{K}^{+}$leak by $95.3 \pm 2.2 \%(n=9)$ while $15 \mathrm{mM}$ TEA reduced the passive leak rate by $85.0 \pm 2.5 \%(n=8)$. The extent of inhibition of passive $\mathrm{K}^{+}$leak by these agents in hypoxic tubules was identical to that in normoxic tubules. The inhibition of $\mathrm{K}^{+}$leak by these two $\mathrm{K}^{+}$channel blockers indicates that the majority of the passive $\mathrm{K}^{+}$leak proceeds via $\mathrm{K}^{+}$channels. The effect of glibenclamide, a blocker of ATP-sensitive $\mathrm{K}^{+}$channels (7), on $\mathrm{K}^{+}$fluxes could not be determined due to interference with the $\mathrm{K}^{+}$-selective electrode. However, measurement of the ATP content of tubules during short-term hypoxia indicated that ATP levels fell to a sufficient extent to cause activation of ATPsensitive $\mathrm{K}^{+}$channels. Fig. 2 shows the ATP content of tubules subjected to the same hypoxia protocol used in the $\mathrm{K}^{+}$flux studies. ATP content was measured at the beginning and end 


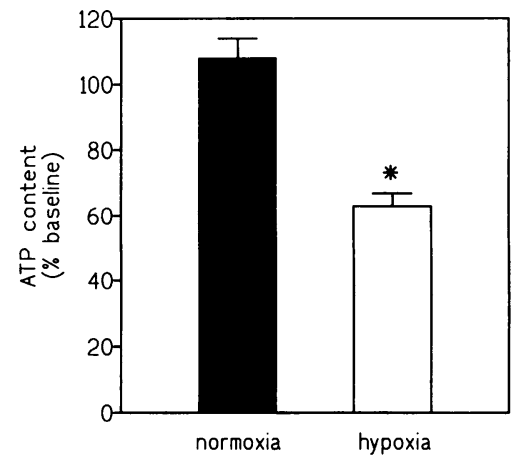

protein $)$. Mean \pm SEM; ${ }^{*} P<0.0001$ vs. normoxia, $n=7$ for normoxia and $n=8$ for hypoxia.

of the 2.5-min period of either normoxia or hypoxia. Tubules maintained under normoxic conditions had good preservation of ATP content ( $108 \pm 6 \%$ of baseline, $n=7$ ). In contrast, after only $2.5 \mathrm{~min}$ of hypoxia, ATP content of the tubules fell by $\sim 40 \%$ ( $63 \pm 4 \%$ of baseline, $n=8, P<0.0001$ vs. normoxia). In this regard, a similar reduction in ATP levels was associated with the activation of ATP-sensitive $\mathrm{K}^{+}$channels in rabbit proximal tubules $(7,19)$. Taken together, the preceding results are consistent with the view that the leak rate of potassium from proximal tubules is increased very early in hypoxia and even precedes the inhibition of the Na,K-ATPase pump. Moreover, the loss of cellular potassium occurs through potassium channels, likely ATP-sensitive $\mathrm{K}^{+}$channels. The present results do not allow us to exclude, unequivocally, the possibility that a component of $\mathrm{K}^{+}$efflux might proceed via other pathways, e.g., $\mathrm{KCl}$ cotransport; however, based on the high degree of inhibition by both barium and TEA, this component must be quite small.

Additional experiments examined the effects of blockers of ATP-sensitive $\mathrm{K}^{+}$channels on ischemic injury in vitro. Freshly prepared proximal tubule suspensions were incubated under hypoxic conditions in the presence or absence of glibenclamide, a blocker of ATP-sensitive $\mathrm{K}^{+}$channels. The concentration of glibenclamide $(500 \mu \mathrm{M})$ was chosen based on data from rabbit proximal tubules (7) which indicated a $K_{\mathrm{i}}$ of $\sim 250 \mu \mathrm{M}$ in these cells. $\mathrm{LDH}$ release into the extracellular fluid was measured as a marker of lethal cell injury. Tubules maintained in oxygenated solutions released only $5.4 \pm 0.9 \%$ of their total $\mathrm{LDH}$ into the extracellular fluid (Fig. $3 A$ ). Incubation of tubules in hypoxic solutions for $30 \mathrm{~min}$ resulted in an increase in LDH release to $36.7 \pm 5 \%$. Finally, incubation of tubules in hypoxic solutions for $30 \mathrm{~min}$ in the presence of glibenclamide resulted in an LDH release of only $23.1 \pm 1.9 \%$ ( $n=5, P=0.036$ vs. hypoxia).

The effect of glibenclamide on the extent of hypoxia-induced DNA damage in proximal tubule suspensions was also examined (Fig. $3 B$ ). Tubules incubated in oxygenated solutions had virtually no DNA damage $(94.3 \pm 1.6 \%$ residual double strand DNA) while tubules incubated in hypoxic solutions for 30 min sustained marked DNA damage $(48.5 \pm 5 \%$ double strand DNA). Glibenclamide ( $500 \mu \mathrm{M})$ conferred a significant degree of protection against DNA damage during hypoxia (84.1 $\pm 5.1 \%, n=5, P<0.0001$ vs. hypoxia) .

Glibenclamide has been shown recently to inhibit the cystic fibrosis transmembrane conductance regulator (CFTR) $\mathrm{Cl}^{-}$ channel (20). A CFTR-like channel has been identified in the
A

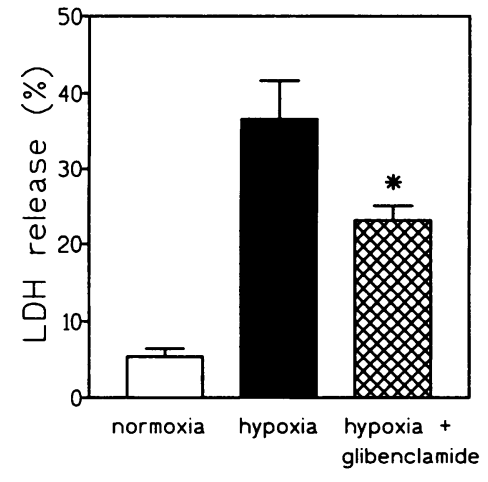

B

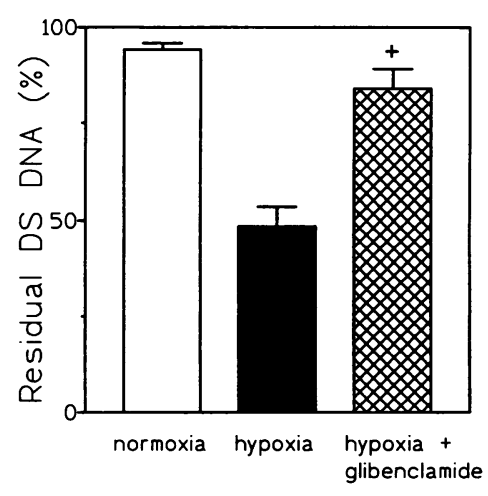

Figure 3. Effects of glibenclamide on hypoxic injury to proximal tubules. Proximal tubules ther normoxic or hypoxic conditions for $30 \mathrm{~min}$. The presence of $500 \mu \mathrm{M}$ glibenclamide throughout the incubation significantly reduced both the hypoxia-induced release of $\mathrm{LDH}$ into the extracellular solution $(A)$ and the extent of DNA damage as determined from the residual doublestrand $(D S)$ DNA $(B)$. Mean \pm SEM; $* P$

$=0.036$ vs. hypoxia; ${ }^{+} P$ $<0.0001$ vs. hypoxia, $n$ $=5$. were incubated under ei-

basolateral membrane of the proximal tubule (21). To determine if the protection afforded by glibenclamide was due to effects on $\mathrm{K}^{+}$channels, rather than CFTR-like $\mathrm{Cl}^{-}$channels, we tested the effects of diazoxide, an opener of ATP-sensitive $\mathrm{K}^{+}$channels (8) but a blocker of CFTR channels (20), and TEA, an unrelated blocker of $\mathrm{K}^{+}$channels, including ATPsensitive $\mathrm{K}^{+}$channels in heart and respiratory tract $(22,23)$, on hypoxic DNA damage. The results (Fig. 4) show clearly that glibenclamide and TEA resulted in similar degrees of protection against DNA damage $(71 \pm 8.7$ and $65.4 \pm 4.5 \%$ residual double strand DNA, respectively, vs. $44.9 \pm 5 \%$ in hypoxia alone, $n=5$, $P<0.03$ for each). In contrast, diazoxide was not protective

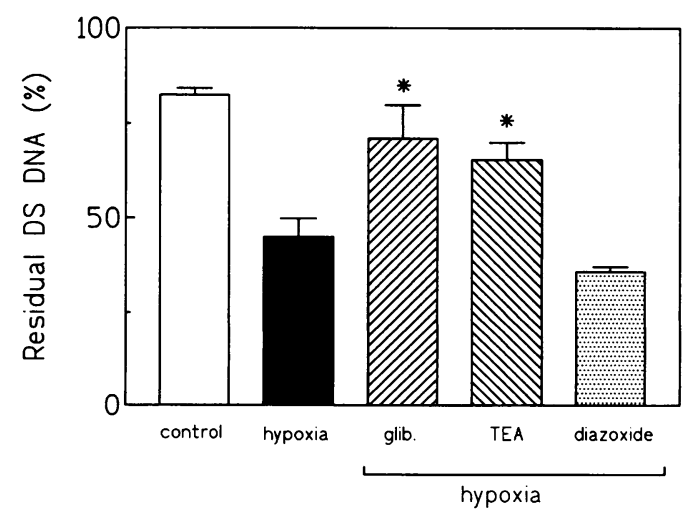

Figure 4. Effects of $\mathrm{K}^{+}$channel modifiers on hypoxia-induced DNA damage. Proximal tubules were exposed to hypoxia for $30 \mathrm{~min}$ in the presence of either $500 \mu \mathrm{M}$ glibenclamide (glib.) $15 \mathrm{mM}$ TEA, or 100 $\mu \mathrm{M}$ diazoxide. $* P<0.035$ vs. hypoxia, $n=5$. 
(35.8 $\pm 1.3 \%$ residual double strand DNA, $n=5, P=0.11$ vs. hypoxia). Thus, the finding that two chemically unrelated $\mathrm{K}^{+}$ channel blockers (glibenclamide and TEA) afforded protection, while diazoxide, a blocker of CFTR $\mathrm{Cl}^{-}$channels but an opener of ATP-sensitive $\mathrm{K}^{+}$channels, afforded no protection against hypoxia-induced DNA damage, is consistent with the view that the glibenclamide effects are mediated through inhibition of potassium channels rather than through interactions with CFTR.

The concentration dependence of protection against hypoxia-induced DNA damage is illustrated in Fig. 5. The affinity for glibenclamide determined from its effects on DNA damage (Fig. $5 B$ ) is almost identical to its affinity for blocking ATPdependent $\mathrm{K}^{+}$channels in the proximal tubule (7). The time course for protection against hypoxia-induced DNA damage is shown in Fig. 6. Delaying the addition of glibenclamide for either 5 or $10 \mathrm{~min}$ after the initiation of hypoxia resulted in significantly less protection against DNA damage. These results are consistent with the prior demonstration that hypoxia-induced DNA damage begins within the first few minutes of hypoxia. ${ }^{\prime}$

\section{Discussion}

Taken together, the results of these studies provide strong support for the view that ATP-sensitive $\mathrm{K}^{+}$channels are activated during renal ischemia and that this activation contributes to hypoxic injury in renal epithelial cells. Measurement of passive $\mathrm{K}^{+}$leak from hypoxic proximal tubules revealed an increased rate of leak at a time when $\mathrm{Na}, \mathrm{K}$-ATPase activity was still normal. Thus, the cellular $\mathrm{K}^{+}$loss which characterizes renal ischemia $(1,4,5)$ is not attributable solely to diminished rates of active $\mathrm{K}^{+}$uptake. During normoxia, ATP-sensitive $\mathrm{K}^{+}$channels provide for coupling of the rates of active $\mathrm{K}^{+}$uptake and passive $\mathrm{K}^{+}$leak in the proximal tubule. Thus, when rates of active $\mathrm{K}^{+}$ uptake via the Na,K-ATPase pump are high, such as during the reabsorption of sodium from the tubular lumen, the increased consumption of ATP lowers the cytosolic ATP levels, thereby activating ATP-sensitive $\mathrm{K}^{+}$channels (7, 19, 24). However, during ischemia the parallelism between pump and leak rates is disrupted. Namely, as ATP levels fall due to decreased production, the rate of active $\mathrm{K}^{+}$uptake will decrease while the rate of passive $\mathrm{K}^{+}$efflux, via ATP-sensitive $\mathrm{K}^{+}$channels, will increase leading to profound cellular $\mathrm{K}^{+}$depletion. Consistent with this view are the observations in isolated perfused hearts that cellular potassium loss begins after only $20 \mathrm{~s}$ of ischemia (25) and can be inhibited by glibenclamide $(25,26)$. In the early stages of hypoxia, we also noted a small increase in the rate of $\mathrm{K}^{+}$uptake via the $\mathrm{Na}, \mathrm{K}$-ATPase. The present studies do not address the mechanisms behind this increase in $\mathrm{Na}, \mathrm{K}$ ATPase activity. However, increases in intracellular $\mathrm{Na}^{+}$concentration or changes in the phosphorylation state of the enzyme might be involved. Additionally, during ischemia in vivo, the accumulation of $\mathrm{K}^{+}$in the extracellular space may tend to increase Na,K-ATPase activity (18). Regardless of the mechanism, any stimulation of Na,K-ATPase activity in the face of impaired ATP production could further deplete cells of ATP and exacerbate subsequent injury.

We also demonstrated, using an in vitro model of ischemic injury, that blockade of ATP-sensitive $\mathrm{K}^{+}$channels is protective against cellular injury. Namely, glibenclamide significantly reduced the release of LDH and the extent of DNA damage in tubules subjected to hypoxia. The concentrations of glibenclamide which resulted in protection against DNA damage (Fig. 5)

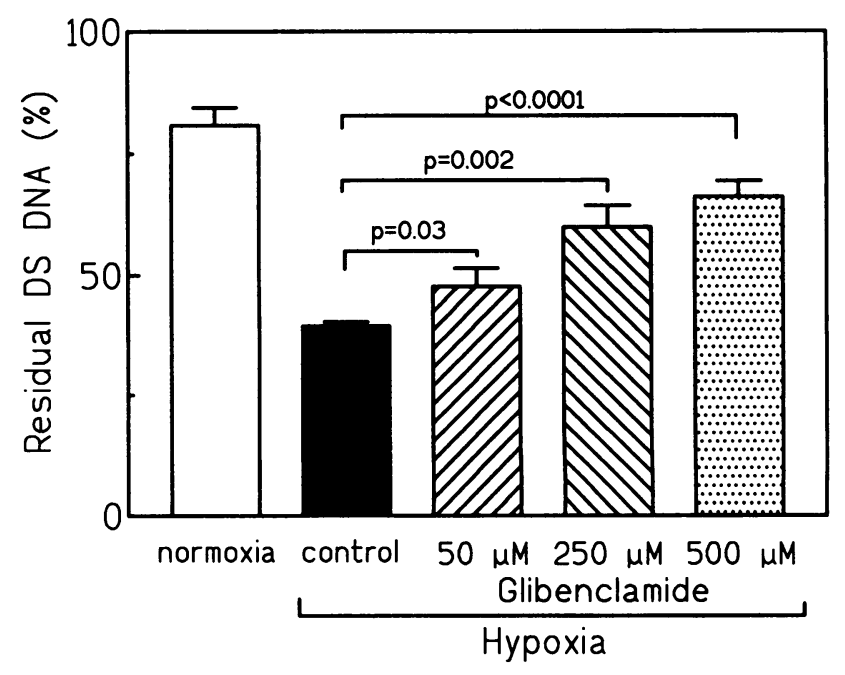

B

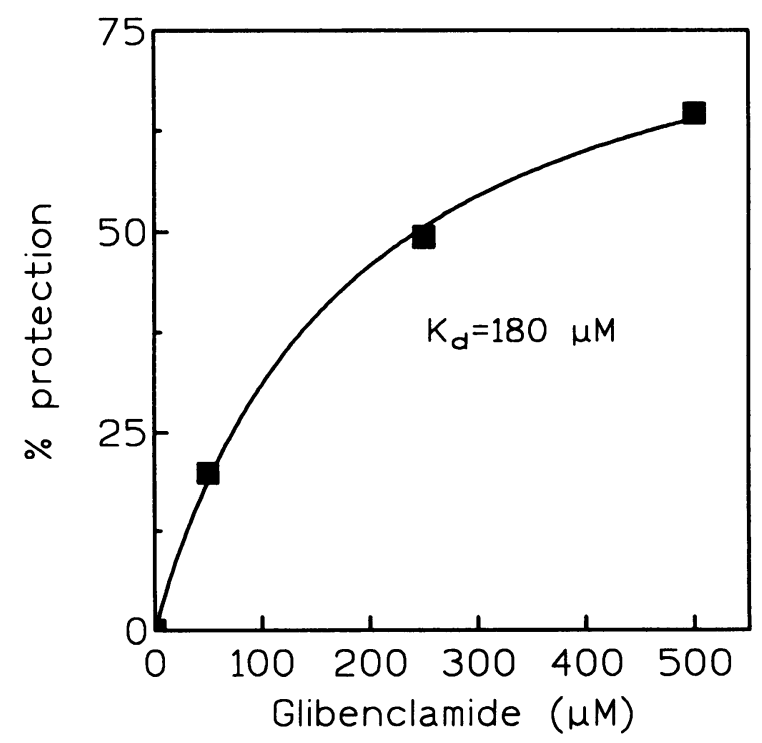

Figure 5. Dose response of effect of glibenclamide to prevent hypoxiainduced DNA damage. $(A)$ Residual double strand $(D S)$ DNA at the end of a 30-min exposure to hypoxia in the presence of varying concentrations of glibenclamide (mean \pm SEM, $n=5$ ). (B) Mean data expressed as the percent protection: $\%=($ normoxia-glibenclamide $) /($ normoxia-control) $\times 100$. The line and $K_{\mathrm{d}}$ value were determined from a fit of the data to the Michaelis-Menton relation: percent protection $=[$ glibenclamide $] /\left(K_{\mathrm{d}}+[\right.$ glibenclamide $\left.]\right) \times 100$.

are identical to those required to block ATP-sensitive $\mathrm{K}^{+}$channels in the proximal tubule (7). Moreover, the early activation ( $2.5 \mathrm{~min}$ ) of a barium-sensitive $\mathrm{K}^{+}$efflux pathway during hypoxia parallels the early requirement for glibenclamide for maximum protection against DNA damage (Fig. 6). Thus, the opening of ATP-sensitive $\mathrm{K}^{+}$channels appears to be a proximate event to DNA damage during hypoxia. These results constitute the first demonstration of a role for ATP-sensitive $\mathrm{K}^{+}$channels 


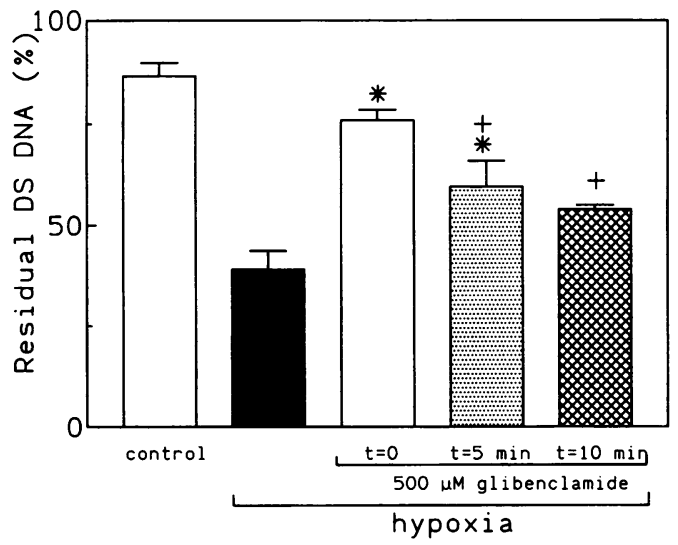

Figure 6. Time course of protection against hypoxia-induced DNA damage. Proximal tubules were exposed to $30 \mathrm{~min}$ of hypoxia with $500 \mu \mathrm{M}$ glibenclamide added either at the start of the hypoxia $(t=0)$ or 5 or 10 min after the initiation of hypoxia. The solid bar denotes tubules exposed to hypoxia in the absence of glibenclamide. $* P<0.05$ vs. hypoxia alone; ${ }^{+} P<0.05$ vs. $t=0, n=3$.

in DNA damage in any model of tissue injury. The mechanism of DNA damage in renal ischemic injury is not fully defined, but may involve the activation of a calcium-dependent endonuclease. ${ }^{1}$ Further studies will be required to determine the mechanism whereby inhibition of ATP-sensitive $\mathrm{K}^{+}$channels prevents this DNA damage.

The protective effects of blockade of ATP-sensitive $\mathrm{K}^{+}$ channels in renal ischemia stand in sharp contrast to its harmful effect in cardiac ischemia. In cardiac ischemia, it is postulated that activation of ATP-sensitive $\mathrm{K}^{+}$channels shortens the duration of the action potential, thereby reducing the net inward movement of $\mathrm{Na}^{+}$and $\mathrm{Ca}^{2+}$ and the contraction duration, and thus tends to reduce the metabolic requirements of the ischemic cells (27). Accordingly, opening of ATP-sensitive $\mathrm{K}^{+}$channels may be protective to the ischemic myocardium while blockade of these channels may exacerbate damage $(25,28)$. Clearly, the role of ATP-sensitive $\mathrm{K}^{+}$channels in an excitable tissue, where the channels regulate contractility and, hence, energy utilization, may be much different than in an epithelial cell.

Finally, the parallel effects of TEA and barium on passive $\mathrm{K}^{+}$leak and of TEA and glibenclamide on DNA damage suggest that TEA is an effective blocker of ATP-sensitive $\mathrm{K}^{+}$channels in the proximal tubule. In contrast, TEA is ineffective as a blocker of ATP-sensitive $\mathrm{K}^{+}$channels found in the collecting duct (29). In this regard, ATP-sensitive $\mathrm{K}^{+}$channels from different tissues form a heterogeneous family of channels with different biophysical, regulatory, and pharmacologic properties (22). The basis for these differences is not yet known, but may derive from the expression of tissue-specific isoforms of these channels or their regulatory subunits. Thus, the ATP-sensitive $\mathrm{K}^{+}$channel in the proximal tubule may represent an isoform distinct from the TEA-insensitive $\mathrm{K}^{+}$channel in the distal tubule. Indeed, a TEA-insensitive ATP-sensitive $\mathrm{K}^{+}$channel has been cloned from the rat kidney (30). In situ hybridization studies have localized this channel to the thick ascending limb and cortical collecting duct but not to the proximal tubule (31).

In summary, the results presented here demonstrate that increased rates of potassium leak precede the inhibition of $\mathrm{Na}, \mathrm{K}-\mathrm{ATPase}$ activity consequent to hypoxia in renal proximal tubules and are coincident with a $40 \%$ decline in cellular ATP concentration. In addition, inhibitors of potassium channels prevented the hypoxia-induced damage to DNA and reduced irreversible cell injury. Thus, the activation of potassium channels, and ATP-sensitive $\mathrm{K}^{+}$channels in particular, is an early response to hypoxia and may play an important role in the production of cellular injury in that setting. Likewise, it seems reasonable to speculate that activation of ATP-sensitive $\mathrm{K}^{+}$channels may also have an important pathogenic role in other forms of injury associated with ATP depletion (32-34).

\section{Acknowledgments}

We thank Linda Traylor and Dainette Priest for their technical assistance.

This work was supported by the Veterans Administration Merit Review Program and by a grant-in-aid from the American Heart Association Arkansas Affiliate.

\section{References}

1. Takano, T., S. P. Soltoff, S. Murdaugh, and L. J. Mandel. 1985. Intracellular respiratory dysfunction and cell injury in short-term anoxia of rabbit renal proximal tubules. J. Clin. Invest. 76:2377-2384.

2. Molitoris, B. A., L. K. Chan, J. I. Shapiro, J. D. Conger, and S. A. Falk. 1989. Loss of epithelial polarity: a novel hypothesis for reduced proximal tubule $\mathrm{Na}^{+}$transport following ischemic injury. J. Membr. Biol. 107:119-127.

3. Zager, R. A., J. Mahan, and A. J. Merola. 1985. Effects of mannitol on the postischemic kidney. Lab. Invest. 53:433-442.

4. Weinberg, J. M. 1985. Oxygen deprivation-induced injury to isolated rabbit kidney tubules. J. Clin. Invest. 76:1193-1208.

5. Weinberg, J. M., J. A. Davis, M. Abarzua, R. K. Smith, and R. Kunkel. 1990. Ouabain-induced lethal proximal tubule injury is prevented by glycine. Am. J. Physiol. 258:F346-F355.

6. Burke, T. J., and R. W. Schrier. 1993. Pathophysiology of cell ischemia. In Diseases of the Kidney. R. W. Schrier and C. W. Gottschalk, editors. Little, Brown and Co., Boston. 1257-1286.

7. Tsuchiya, K., W. Wang, G. Giebisch, and P. A. Welling. 1992. ATP is a coupling modulator of parallel Na,K-ATPase-K-channel activity in the renal proximal tubule. Proc. Natl. Acad. Sci. USA. 89:6418-6422.

8. Hurst, A. M., J. S. Beck, R. Laprade, and J.-Y. Lapointe. 1993. $\mathrm{Na}^{+}$ pump inhibition downregulates an ATP-sensitive $\mathrm{K}^{+}$channel in rabbit proximal convoluted tubule. Am. J. Physiol. 264:F760-F764.

9. Liepins, A., and H. B. Younghusband. 1987. A possible role for $\mathrm{K}^{+}$channels in tumor cell injury. Exp. Cell Res. 169:385-394.

10. Doctor, R. B., and L. J. Mandel. 1991. Minimal role of xanthine oxidase and oxygen free radicals in rat renal tubular reoxygenation injury. J. Am. Soc. Nephrol. 1:959-969.

11. Bergmeyer, H. U., E. Bernt, and B. Hess. 1963. Lactic dehydrogenase. In Methods of Enzymatic Analysis. H. U. Bergmeyer, editor. Academic Press, New York. 736-743.

12. Schraufstätter, I., P. A. Hyslop, J. H. Jackson, and C. G. Cochrane. 1988. Oxidant-induced DNA damage of target cells. J. Clin. Invest. 82:1040-1050.

13. Birnboim, H. C., and J. J. Jevcak. 1981. Fluorometric method for rapid detection of DNA strand breaks in human white blood cells produced by low doses of radiation. Cancer Res. 41:1889-1892.

14. Kone, B. C., D. Kikeri, M. L. Zeidel, and S. R. Gullans. 1989. Cellular pathways of potassium transport in renal inner medullary collecting duct. Am. J. Physiol. 256:C823-C830.

15. Soltoff, S. P., and L. J. Mandel. 1986. Potassium transport in the rabbit renal proximal tubule: effects of barium, ouabain, valinomycin, and other ionophores. J. Membr. Biol. 94:153-161.

16. Kone, B. C., H. R. Brady, and S. R. Gullans. 1989. Coordinated regulation of intracellular $\mathrm{K}^{+}$in the proximal tubule: $\mathrm{Ba}^{2+}$ blockade down-regulates the $\mathrm{Na}^{+}, \mathrm{K}^{+}$-ATPase and up-regulates two $\mathrm{K}^{+}$permeability pathways. Proc. Natl. Acad. Sci. USA. 86:6431-6435.

17. Vilsen, B. 1992. Functional consequences of alterations to Pro-328 and Leu-332 located in the 4th transmembrane segment of the $\alpha$-subunit of the rat kidney Na,K-ATPase. FEBS (Fed. Eur. Biochem. Soc.) Lett. 314:301-307.

18. Jewell, E. A., and J. B. Lingrel. 1991. Comparison of the substrate dependence properties of the rat $\mathrm{Na}, \mathrm{K}$-ATPase $\alpha 1, \alpha 2$, and $\alpha 3$ isoforms expressed in HeLa cells. J. Biol. Chem. 266:16925-16930.

19. Beck, J. S., S. Breton, H. Mairbaurl, R. Laprade, and G. Giebisch. 1991. 
Relationship between sodium transport and intracellular ATP in isolated perfused rabbit proximal convoluted tubule. Am. J. Physiol. 261:F634-F639.

20. Sheppard, D. N., and M. J. Welsh. 1992. Effect of ATP-sensitive K ${ }^{+}$ channel regulators on cystic fibrosis transmembrane conductance regulator chloride currents. J. Gen. Physiol. 100:573-591.

21. Segal, A. S., J. Geibel, and E. L. Boulpaep. 1993. A chloride channe resembling CFTR on the basolateral membrane of rabbit proximal tubule. J. Am. Soc. Nephrol. 4:879a. (Abstr.)

22. Ashcroft, S. J. H., and F. M. Ashcroft. 1990. Properties and functions of ATP-sensitive K-channels. Cell. Signalling. 2:197-214.

23. Kakei, M., A. Noma, and T. Shibasaki. 1985. Properties of adenosinetrophosphate-regulated potassium channels in guinea-pig ventricular cells. $J$. Physiol. 363:441-462.

24. Beck, J. S., A. M. Hurst, J.-Y. Lapointe, and R. Laprade. 1993. Regulation of basolateral $\mathrm{K}$ channels in proximal tubule studied during continuous microperfusion. Am. J. Physiol. 264:F496-F501

25. Mitani, A., K. Kinoshita, K. Fukamachi, M. Sakamoto, K. Kurisu, Y. Tsuruhara, F. Fukumura, A. Nakashima, and K. Tokunaga. 1991. Effects of glibenclamide and nicorandil on cardiac function during ischemia and reperfusion in isolated perfused rat hearts. Am. J. Physiol. 261:H1864-H1871.

26. Kantor, P. F., W. A. Coetzee, E. E. Carmeliet, S. C. Dennis, and L. H. Opie. 1990. Reduction of ischemic $\mathrm{K}^{+}$loss and arrhythmias in rat hearts. Circ Res. 66:478-485.

27. Ten Eick, R. E., D. W. Whalley, and H. H. Rasmussen. 1992. Connections: heart disease, cellular electrophysiology, and ion channels. FASEB (Fed. Am Soc. Exp. Biol.) J. 6:2568-2580.

28. Auchampach, J. A., M. Maruyama, I. Cavero, and G. J. Gross. 1991. The new $\mathrm{K}^{+}$channel opener aprikalim (RP 52891 ) reduces experimental infarct size in dogs in the absence of hemodynamic changes. J. Pharmacol. Exp. Ther. 259:961-967.

29. Wang, W., H. Sackin, and G. Giebisch. 1992. Renal potassium channels and their regulation. Annu. Rev. Physiol. 54:81-96.

30. Ho, K., C. G. Nichols, W. J. Lederer, J. Lytton, P. M. Vassilev, M. V. Kanazirska, and S. C. Hebert. 1993. Cloning and expression of an inwardly rectifying ATP-regulated potassium channel. Nature (Lond.). 362:31-37.

31. Lee, W. -S., K. Ho, M. A. Hediger, and S. C. Hebert. 1993. Localization of the ATP-regulated potassium channel (ROMK) mRNA in rat kidney by tissue and single nephron in situ hybridization. J. Am. Soc. Nephrol. 4:871a. (Abstr.)

32. Almeida, A. R. P., J. F. M. Wetzels, D. Bunnachak, T. J. Burke, C. Chaimovitz, W. S. Hammond, and R. W. Schrier. 1992. Acute phosphate depletion and in vitro proximal tubule injury: protection by glycine and acidosis. Kidney Int. 41:1494-1500.

33. Groves, C. E., R. G. Schnellmann, P. P. Sokol, T. G. Steffans, and E. A. Lock. 1991. Pentachlorobutadienyl- $L$-cysteine (PCBC) toxicity: the importance of mitochondrial dysfunction. J. Biochem. Toxicol. 6:253-260.

34. Schnellmann, R. G., F. P. Q. Ewell, M. Sgambati, and L. J. Mandel. 1987. Mitochondrial toxicity of 2-bromohydroquinone in rabbit renal proximal tubules. Toxicol. Appl. Pharmacol. 90:420-426. 